\title{
Food consumption rated by quality index diet (IQD) in pregnant women with gestational diabetes mellitus
}

\author{
Lilian Barros de Sousa Moreira Reiš, Iracema de Mattos Paranhos Calderon, Cláudia Vicari Bolognani, Adriano Dias, \\ Adriano Dias
}

From 20th Brazilian Diabetes Society Congress

Porto Alegre, Brazil. 11-18 November 2015

\section{Background}

Proper nutrition is important during pregnancy, and especially in those complicated by diabetes.

\section{Objective}

Assess food intake by diet quality index (IQD) in pregnant women with Melitos Gestational Diabetes (GDM).

\section{Materials and methods}

Cohort study transversal and descriptive in 65 pregnant women with GDM. Dietary intake was determined by 24-hour dietary recall (24HR) and a Food Frequency Questionnaire (FFQ), and qualified IQD.

\section{Results and discussion}

$67.7 \%$ of the women had body mass index (BMI) before pregnancy $\geq 25 \mathrm{~kg} / \mathrm{m} \mathrm{2}$. The caloric value was observed in $24 \mathrm{HR} 1657 \pm 532 \mathrm{kcal}$. According to the IQD, the diet was adequate in $51.6 \%$ of pregnant women. The worst score components were vegetables and dairy products. The intake of meat, sodium and total fat received the highest scores.

\section{Conclusion}

IQD, referenced by $24 \mathrm{HR}$ and applied as a tool for nutritional assessment showed that the diet was considered inadequate or in need of adjustment in half of the pregnant population evaluated. These inadequacies were related to low intake of vegetables and milk and milk products. These Results indicate the need to prioritize educational prenatal, to encourage the consumption of

\footnotetext{
* Correspondence: lilianb.moreira@yahoo.com.br Secretaria de Saúde do Distrito Federa/FMB-UNESP, Asa Sul, Brazil
}

vegetables and dairy products among these pregnant women with GDM.

Published: 11 November 2015

doi:10.1186/1758-5996-7-S1-A67

Cite this article as: de Sousa Moreira Reis et al:: Food consumption rated by quality index diet (IQD) in pregnant women with gestational diabetes mellitus. Diabetology \& Metabolic Syndrome 2015 7(Suppl 1):A67.
Submit your next manuscript to BioMed Central and take full advantage of:

- Convenient online submission

- Thorough peer review

- No space constraints or color figure charges

- Immediate publication on acceptance

- Inclusion in PubMed, CAS, Scopus and Google Scholar

- Research which is freely available for redistribution

Submit your manuscript at www.biomedcentral.com/submit
() Biomed Central 